\title{
Correction to: On diverse arts: crucible metallurgy and the polymetallic cycle at Scandinavia's earliest Viking town, Ribe (8th-9th C. CE), Denmark
}

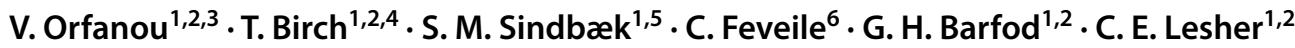 \\ Published online: 25 September 2021 \\ (c) The Author(s) 2021
}

\section{Correction to: Archaeological and Anthropological Sciences (2021) 13: 81} https://doi.org/10.1007/s12520-021-01,308-1

The article "On diverse arts: crucible metallurgy and the polymetallic cycle at Scandinavia's earliest Viking town, Ribe (8th-9th c. CE), Denmark", was originally published Online First without Open Access. After publication in volume 13 , issue 5 , the author decided to opt for Open Choice and to make the article an Open Access publication. Therefore, the copyright of the article has been changed to $\odot$ The Author(s) 2020 and the article is forthwith distributed under the terms of the Creative Commons Attribution 4.0 International License, which permits use, sharing, adaptation, distribution and reproduction in any medium or format, as long as you give appropriate credit to the original author(s) and the source, provide a link to the Creative Commons licence, and indicate if changes were made. The images or other third party material in this article are included in the article's Creative Commons licence, unless indicated otherwise

The original article can be found online at https://doi.org/10.1007/ s12520-021-01308-1.

V. Orfanou

vana.orfanou@ucd.ie

1 Centre for Urban Network Evolutions (UrbNet), Aarhus University, 8270 Højbjerg, Denmark

2 Aarhus Geochemistry and Isotope Research (AGiR) Platform, Department of Geoscience, Aarhus University, 8000 Aarhus, Denmark

3 School of Archaeology, University College Dublin, Belfield Dublin 4, Ireland

4 Moesgaard Museum, 8270 Højbjerg, Denmark

5 School of Culture and Society, Aarhus University, 8270 Højbjerg, Denmark

6 Museum of Southern Jutland, 6270 Tønder, Denmark in a credit line to the material. If material is not included in the article's Creative Commons licence and your intended use is not permitted by statutory regulation or exceeds the permitted use, you will need to obtain permission directly from the copyright holder. To view a copy of this licence, visit http://creativecommons.org/licenses/by/4.0.

The original article was corrected.

Acknowledgements We also sincerely thank the Onassis Foundation for their generous support with Open Access fees.

Open Access This article is licensed under a Creative Commons Attribution 4.0 International License, which permits use, sharing, adaptation, distribution and reproduction in any medium or format, as long as you give appropriate credit to the original author(s) and the source, provide a link to the Creative Commons licence, and indicate if changes were made. The images or other third party material in this article are included in the article's Creative Commons licence, unless indicated otherwise in a credit line to the material. If material is not included in the article's Creative Commons licence and your intended use is not permitted by statutory regulation or exceeds the permitted use, you will need to obtain permission directly from the copyright holder. To view a copy of this licence, visit http://creativecommons.org/licenses/by/4.0/.

Publisher's note Springer Nature remains neutral with regard to jurisdictional claims in published maps and institutional affiliations. 